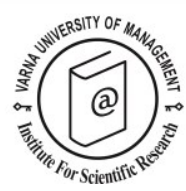

\title{
Community involvement and sustainable rural tourism development: perspectives from the local communities
}

\author{
Sook-Fun Fong ${ }^{1 *}$ and May-Chiun Lo ${ }^{2}$
}

Received: 12/12/2014 Accepted: 01/07/2015

\footnotetext{
1 Institute of Social Informatics and Technological Innovations (ISITI), University Malaysia Sarawak, 94300 Sarawak, Malaysia; tel: +6011 12027290; e-mail: elsiefong25@gmail.com

2 Faculty of Economics and Business; University Malaysia Sarawak; 94300 Sarawak; Malaysia; tel: +60 82 581154; e-mail: mclo@feb.unimas.my

* Corresponding author
}

\begin{abstract}
The aim of this study is to examine the relationship between local communities' involvement and sustainable rural tourism development in the existing tourism industry in Kuching namely, Kampung Annah Rais and Kampung Darul Islam Belimbing. In tourism industry, the way how tourism stakeholders are pleased with mass tourism have been deeply affecting the achievement of sustainable rural tourism development. A questionnaire survey was carried out among the local communities who are currently staying and have been staying in these rural tourism destinations for more than a year. A sample of 113 usable questionnaires was obtained. Four hypotheses were developed regarding the effects of participation in decision making, knowledge sharing, empowerment, and community knowledge about tourism on social, cultural, economic, and environmental sustainability. The findings suggest that local communities' participation in decision making, empowerment, and community knowledge about tourism do affect the sustainability of rural tourism development. Interestingly, findings indicated that knowledge sharing does not show positive relationship on sustainable rural tourism development. It is believed that poor relationship among the tourism stakeholders influences the effectiveness of knowledge sharing. Suggestions for practical implications and future research are discussed further.
\end{abstract}

(C) 2015 Varna University of Management. All rights reserved

Keywords: community involvement; decision making; knowledge sharing; empowerment; community sustainable rural tourism development

Citation: Fong, S. F., M. C. Lo (2015) Community involvement and sustainable rural tourism development: perspectives from the local communities. European Journal of Tourism Research 11, pp. $125-146$

\section{Introduction}

Rural tourism or known as non-urban tourism includes a wide range of local activities, natural, attractions, facilities, transportation, various amenities, marketing and information systems which are located outside of the cities (Sharpley \& Sharpley, 1997). Previous researchers (e.g., Oppermann, 1996) posited 
that rural tourism has been used interchangeably with various terms namely, agro-tourism, equestrian tourism, hunting tourism, rural heritage tourism, adventure tourism, ecotourism, and nature-based tourism. Farm-stay, home-stay, and other accommodation providers, activity-based businesses, retail outlets, gardens, museums, and other cultural and heritage products are categorized as rural tourism businesses in some countries (Warren \& Taylor, 1999).

Rural tourism in Malaysia was introduced as a new form of tourism by the Malaysian government during the Seventh Malaysia Plan period (1996-2000) and it is still the main focus as one of the National Key Economic Areas (NKEA) under the Tenth Malaysia Plan to create employment opportunities and to increase the income levels among the rural communities (Nair, Munikrishnan, Rajaratnam, \& King, 2014). In sum, tourism in Malaysia serves as the catalyst to motivate the economic growth and, in particular, improve the local communities' standard of living (Briedenhann \& Wickens, 2004). Thus, it is important to ensure the sustainability of rural tourism development in Malaysia.

Rural tourism offers differentiated product offerings than urban tourism as rural areas are located outside of the cities and enables the tourists to participate in non-urban activities (e.g., hunting and jungle trekking) (Pesonen, Komppula, Kronenberg, \& Peters, 2011). As a result, rural tourism is highly demanded among tourists who seek out for rural experiences such as the rural character of the places, natural environment, and the characteristic of the local communities. Nonetheless, social, cultural, economic, and environmental sustainability are affected due to mass tourism which was insensitive to the elements of sustainable rural tourism development (Fiorello \& Bo, 2012). As such, this study investigated the impact of local communities' involvement on sustainable rural tourism development. Past researchers (e.g., Thongma, Leelapattana, \& Hung, 2011; Hjalager, 2010) posited that local communities are the ones who are familiar with the tourists and with their local cultural activities. Hence, their involvement and support are essential to the success and development of rural tourism. However, many tourism authorities and stakeholders neglected this important fact and opposed the idea of local communities' involvement in rural tourism development (Tosun, 2006; Liu, 2006). Moreover, there is a lack of participation among the local communities in rural tourism due to paternalism, racism, clientelism, lack of expertise, and lack of financial resources which hinder the process of community participation (Dogra \& Gupta, 2012; Tosun, 2000). Therefore, it is vital to gain local communities' involvement and support when it is related to sustainable rural tourism development.

The purpose of this research is to evaluate the impact of local communities' involvement in tourism activities on sustainable rural tourism development in Kampung Annah Rais and Kampung Darul Islam Belimbing, two existing rural tourism destinations in Kuching, Sarawak, Malaysia. Kampung Annah Rais and Kampung Darul Islam Belimbing are located in the Padawan District at the foothill of Borneo Highlands near to the mountains marking the border to Kalimantan, approximately $60 \mathrm{~km}$ away from the city of Kuching, Sarawak. As both tourist destinations are remotely located, it takes about 1.5 hours drive from Kuching. The population of the local communities in these rural tourism destinations are small and they are mainly Bidayuh and Bidayuh Muslims. The main source of livelihood in these rural tourism destinations is agriculture. Besides, the distinctive features of their landscapes and wooden long houses are part of their rural lifestyle. In addition, Tuai Rumah or known as the longhouse headmen is appointed to govern these rural destinations.

Thus, this study was designed as follows. Based on the previous researches, the section on hypotheses proposed a series of hypotheses on the 4 types of local community involvement in tourism activities namely, participation in decision making, knowledge sharing, empowerment, and community knowledge about tourism on sustainable rural tourism development namely, social, cultural, economic, and environmental sustainability. The methodology section presents the data and the method used to analyse empirically the hypotheses developed in rural tourism in 
Kampung Annah Rais and Kampung Darul Islam Belimbing. The section on the results presents the findings while the last section focuses on the conclusions, future research, and some of the limitations of this study.

\section{Conceptual Background and Hypotheses Community Involvement}

Community involvement is referred to residents who are involved in sharing issues and knowledge about their lives and are involved in daily activities within their communities (Lee, 2013). Local communities who are involved in tourism activities have been repeatedly addressed as an action of support towards tourism development in their communities (Simmons, 1994). This is further supported by Caneday and Zeiger (1991) that residents' involvement in tourism activities will influence their attitudes and perception towards tourism.

Community involvement includes sharing knowledge, gaining commitment from the communities, and participation in decision making process and these will in turn achieve tourist satisfaction and sustainable rural tourism development (MacDonald \& Jolliffe, 2003). Thus, it is believed that community involvement plays a pivotal role in sustaining rural tourism development (Gursoy \& Rutherford, 2004; Nicholas, Thapa, \& Ko, 2009).

\section{Participation in Decision Making}

Participation in decision making can be defined as the totality forms of direct (personal) or indirect (through representatives or institutions) and of intensities, ranging from minimal to comprehensive, by which individual, groups, and collectives secure their interests or contribute to the choice process through selfdetermined choices among possible actions during the decision process (Heller, Pusic, Strauss, \& Wilpert, 1998). Bhuiyan (2010) noted that participation in decision making has a large impact on an individual's attitude, belief, and motivation.

Past researchers (e.g., Aas, Ladkin, \& Fletcher, 2005; Simmons, 1994) opined that involving the local community in management and decision making process enables the local community to have an in-depth understanding about the benefits of integrating tourism into their local economy. As a result, local community who involved in the decision making process will increase their understanding about tourism and in turn reduce their uncertainty. Besides, local community should be consulted when it is related to tourism decision making in their community (Choi \& Sirakaya, 2005). This is so because the success and sustainability of tourism depend on the active involvement of these local communities. Hence, local communities' participation in decision making is viable as it will increase the productivity and profit of the particular tourist destination.

\section{Knowledge Sharing}

Knowledge sharing is the process where individuals mutually exchange their knowledge with others and jointly create new knowledge (Van Den Hooff \& De Ridder, 2004). Besides, Ryu, Ho, and Han (2003) posited that knowledge sharing is an individual's behaviour in disseminating his or her knowledge to another person. The term knowledge sharing has been used interchangeably and synonymously with some other terms namely, knowledge flows, knowledge transfer, and diffusion of knowledge by past researchers (Cooper, 2006). Knowledge sharing is time consuming in which it does not show immediate success and it depends on an individual's willingness to share knowledge, time, and have high intention in order to make knowledge understood, absorbed, and used by others (Alavi \& Leidner, 2001; Ipe, 2003). Effective knowledge sharing will be a source of competitive advantage to an organization, industry, and country due to it is hard to be imitate or substitute by others (Spender, 1996; Matzler \& Mueller, 2011). Moreover, MacDonald and Jolliffe (2003) revealed that local communities who share their knowledge will help to enhance tourist experience. In addition, effective knowledge sharing will contribute to successful tourism development (Shaw \& William, 2009). Therefore, an individual or organization which is capable of transferring knowledge successfully to others will achieve great performances.

\section{Empowerment}

Empowerment is defined as the capacity of individuals or groups in determining their own 
affairs and it is a process where people take control over the factors that influence their lives (Scheyvens, 1999). Furthermore, Sofield (2003) posited that empowerment is a shift in balance between the powerful and powerless, between the dominant and dependent. Past researchers (e.g., Arnstein, 1969) posited that citizen participation must be accompanied by power redistribution or known as empowerment. This is so because local communities have the ability to make wise decisions and to seek out solutions to solve the problems in their community. This is further supported by Tosun and Timonthy (2003) that local community are knowledgeable about what will work and what will not work in local conditions. In addition, community empowerment is used to trigger the ability of the local communities to manage tourism development in their community (Cole, 2006). Hence, it is important to distribute power between and within the community groups in order to achieve sustainable rural tourism development.

\section{Community Knowledge about Tourism}

Community knowledge about tourism or known as local tourism awareness refers to the level of local knowledge on tourist, tourism, and its impacts (Saarinen, 2010). Rural tourism development is affected by factors such as economic development, humanitarian attitudes, environment, social values, and knowledge (Poostchi, 1986). According to Zapata, Hall, Lindo, and Vanderschaeghe (2011), local community who are knowledgeable about tourism development projects can reduce the poverty level in their community. This is so because individuals that are knowledgeable about tourism will recognize the costs and benefits that they will receive from tourism (Andereck, Valentine, Knopf, \& Vogt, 2005). As a result, they will be motivated to participate in tourism activities in their community and in turn improve local economies. In addition, individuals who have wide knowledge about tourism could influence the development of the tourism in a community (Yang, 2012). Thus, sufficient community knowledge about tourism could help local communities be active participants in tourism development and in turn achieve sustainable rural tourism development.

\section{Sustainable Rural Tourism Development}

Sustainable tourism focuses on the fluid relationship between human and physical environment (McAreavey \& McDonagh, 2011). Furthermore, Rattanasuwongchai (1998) posited that sustainable development refers to "rural development" and "rural tourism" in which are the keys to raise the local communities' standard of living and at the same time used to ensure the welfare of their present and future generations. Sustainable tourism is highly demanded due to mass tourism which was insensitive to its social, cultural, economic, and environmental condition of tourist destinations (Fiorello \& Bo, 2012). As a result, sustainable tourism is used to avoid the negative effects of tourism on local destinations (Dolnicar, 2006). In this study, sustainable rural tourism development was employed. Sustainable rural tourism development has been defined as a tourism which focuses on the appropriate policies and strategies that could guarantee the benefits while restricting its negative impacts of rural tourism in rural community (Ertuna \& Kirbas, 2012). There are four dimensions in sustainable rural tourism development, namely social, cultural, economic, and environmental sustainability (Timur \& Getz, 2009). Hence, the following sections discusses on the four dimensions of sustainable rural tourism development.

\section{Social Sustainability}

Social sustainability is said to be achieved when a tourist destination manages to preserve the historical and cultural heritage (Sanagustin Fons, Fierro, \& y Patino, 2011). Tourism, according to Timur and Getz (2009), may lead to social problems such as traffic congestion, construction projects, crimes, mixed effects on quality of life, and changes in the communities' identity. Besides, tourism can influence local communities' moral values due to monetary benefits (Archer, Cooper, \& Ruhanen, 2005). On the other hand, tourism could enhance the social relationship among various stakeholders (Barnett \& Casper, 2001). As such, local community participation in rural tourism is important to achieve positive social performance such as a decrease in vandalism, gambling, drugs, and prostitution (Deery, Jago, \& Fredline, 2012; Eshliki \& Kabousi, 2012; Thongma et al., 2011). 


\section{Cultural Sustainability}

Culture is a set of traits that are shared by the "characteristics" of human societies and are transmitted by non-genetic means (Mulder, Nunn, \& Towner, 2006). Tourism which views positively has changed the lifestyle of the local communities and on the other hand, it may be interpreted negatively as an indication of acculturation (Brunt \& Courtney, 1999). In other words, tourism may cause long term changes in the community's values, beliefs, and cultural practices. Thus, local community involvement in tourism activities is the key element to preserve the traditional culture in a community (Dorobantu \& Nistoreanu, 2012).

\section{Economic Sustainability}

Rural tourism has been a panacea for poverty in rural areas. Rural tourism provides employment opportunities, increase local prosperity, conserve the environment, and preserve the cultural assets and in turn ensure greater benefits for tourism stakeholders (McAreavey \& McDonagh, 2011). However, there are tourism stakeholders who are only interested in the short term profits without considering the long term social and physical aspects of tourism which lead to drastic decrease in the number of tourists (Costa, 2001). Therefore, active involvement and participation of local community in rural tourism development process are the prerequisites to achieve sustainability and improve the overall welfare in the community (Thongma et al., 2011; Ertuana \& Kirbas, 2012).

\section{Environmental Sustainability}

Environmental sustainability which is compatible with the maintenance of the ecological processes, biological diversity, and biological resources are important in order to provide an environment that is attractive for tourists to visit (World Travel and Tourism Council (WTTC), World Tourism Organization (WTO), \& Earth Council, 1995; Sanagustin Fons, Fireeo, \& y Patino, 2011). Rural tourism is seen as the optimal solution to preserve the nature, landscape, and environment. On the other hand, Cawley and Gillmor (2008) posited that tourism could harm the environment and the community. Thus, community involvement in rural tourism development process plays a crucial role in protecting the environmental sustainability in a tourist destination (Dorobantu \& Nistoreanu, 2012).

\section{Development of Hypotheses}

Participation in Decision Making and Sustainable Rural Tourism Development

Participation in decision making enables individuals or groups to secure their interest and in turn contribute to the decision making process. Thongma, Leelapattana, and Hung (2011) indicated that local communities who involved in decision making process will affect the survival of a tourist destination. SantanaMedina, Franco-Maass, Sanchez-Vera, Imbernon, and Nava-Bernal (2013) stated that local communities are capable of identifying, selecting, and measuring the sustainability indicators that will benefit the tourist destinations. Moreover, local communities who are familiar with their own community will make wise decisions on dealing with the problems and prospects of tourism development in their community (Aas, Ladkin, \& Fletcher, 2005). As such, there are several researchers who hypothesized that community participation in decision making is positively related to sustainable rural tourism development (Ertuna \& Kirbas, 2012; Roseland, 2012; Li, 2006; Snepenger, O'Connell, \& Snepenger, 2001). Thus, the following hypothesis has been developed.

$\mathrm{H} 1$ : Participation in decision making is positively related to sustainable rural tourism development as such social, cultural, economic, and environmental sustainability.

\section{Knowledge Sharing and Sustainable Rural Tourism Development}

Knowledge sharing enables individuals or groups to provide or receive information and skills from the interaction and communication among interest groups (Cohen \& Bailey, 1997). Hwang, Stewart, and Ko (2012) hypothesized that there are positive associations between knowledge sharing and sustainable rural tourism development. Local community who are willing to share their knowledge with tourism stakeholders will enhance the prospects for sustainable rural tourism development. This is further noted by Ertuna and Kirbas (2012) that networking such as exchanging information between the local 
communities and tourism stakeholders will contribute to successful local tourism development. Knowledge sharing enhance innovation and enables the local communities and tourism stakeholders to achieve social, cultural, economic, and environmental sustainability in a tourist destination. Furthermore, past researchers have elucidated that there are positive relationship between knowledge sharing and sustainable rural tourism development (Hall, 2011; Sorensen, 2007; Cooper, 2006; Jackson, 2006; Jackson \& Murphy, 2006). Therefore, the following hypothesis has been established.

$\mathrm{H} 2$ : Knowledge sharing is positively related to sustainable rural tourism development as such social, cultural, economic, and environmental sustainability.

\section{Empowerment and Sustainable Rural Tourism Development}

Empowerment enables individuals or groups to gain control or authority over the land, rules, and to establish mechanisms to enforce the rules (Cole, 2006; Sofield \& Li, 2007). Empowerment is recognized as the important key to achieve sustainable rural tourism development (Coria \& Calfucura, 2012; Choi \& Murray, 2010; Sofield, 2003). Local communities who are empowered in tourism development are found to have significant impact on social, cultural, economic, and environmental sustainability (Boley \& McGehee, 2014). Empowerment enables local communities to gain control or power over tourism development in their community and in turn influence the social lifestyle, economic development, and environmental protection of a particular tourist destination. Furthermore, community empowerment enables local communities to have a voice in tourism decision making process which in turn will bring maximum benefits to the tourist destinations (Dwyer, 2005). Hence, the following hypothesis has been developed.

H3: Empowerment is positively related to sustainable rural tourism development as such social, cultural, economic, and environmental sustainability.
Community Knowledge about Tourism and Sustainable Rural Tourism Development

According to Moscardo (2011), those who claim to have knowledge about tourism are knowledgeable about tourists, tourism, and its impacts and this knowledge is useful to make wise decisions to solve the range of barriers to sustainable rural tourism development. Community knowledge or awareness about tourism is important in order for local communities to participate actively in tourism and to have control over tourism development and practices. As such, this may in turn enable the local communities to recognize the benefits of tourism. Besides, Reid, Mair, and George (2004) highlighted that community's understanding of tourism is a crucial element to tourism development. Communities who have wide knowledge about tourism will create control mechanisms and sense of ownership of tourism and resources, which will in turn generate benefits for a tourist destination. As a result, it is hypothesized that community knowledge about tourism is positively associated with sustainable rural tourism development (Zapata, Hall, Lindo, \& Vanderschaeghe, 2011; Saarinen, 2010; Novelli \& Gebhardt, 2007; Tosun, 2006). Therefore, the following hypothesis has been developed.

$\mathrm{H} 4$ : Community knowledge is positively related to sustainable rural tourism development as such social, cultural, economic, and environmental sustainability.

\section{Resource-Based View Theory}

Resource-based view in an organization is critical for an organization to achieve sustainable competitive advantage or superior performance (Henry, 2008; Fahy, 2000). There are three unique components in resourcebased theory, namely tangible assets, intangible assets, and capabilities (Fahy \& Smithee, 1999). In this study, participation in decision making, knowledge sharing, empowerment, and community knowledge about tourism are categorized as capabilities, the third sub-group of resource-based theory in which it can be referred to the skills of individuals, groups, organizational routines, and interactions based that are difficult to be imitated (Itami, 1987). Thus, these capabilities 
in resource-based view theory can be concluded as the key determinants to achieve sustainable rural tourism development.

\section{Comparative Advantage Theory}

Comparative advantage theory is applied when an organization has resources that are rare, valuable, difficult to duplicate, and nonsubstitutable that enables the organization to produce a market offering that has superior value and can be produced at a lower cost (Hunt \& Morgan, 1995). In this study, comparative advantage in a destination exists when the visitors perceive that the destination provide superior value. In other words, sustainable rural tourism development namely, social, cultural, economic, and environmental sustainability are categorized as comparative advantage in a tourist destination. Therefore, comparative advantage in a destination is crucial to earn a market position in this highly competitive tourism industry.

\section{Methodology}

With the aim to generalise the findings on respondents who have been staying in rural tourism destinations namely, Kampung Annah Rais and Kampung Darul Islam Belimbing, Kuching, Sarawak, Malaysia for more than a year, the population of the present study consists of respondents who are currently staying in these rural tourism destination. Prior to the actual data collection, a pre-test was conducted in order to ascertain how well the questionnaire works (Hunt, Sparkman, \& Wilcoz, 1982). The questionnaires were given to 7 respondents in Kampung Annah Rais to identify questions that may cause confusion to the local communities. As a result, some questions were reworded to suit the context of the local communities in these rural tourism destinations. A total of 180 questionnaires were distributed personally to the local communities who have been staying in these rural tourism destinations for more than a year. The selection of these respondents was based on convenient sampling method. Out of 180 questionnaires distributed, $133(73.89 \%)$ were returned, and only 113 sets were usable.

The first section was designed to collect the personal and demographic profile of the respondents. Section 2 required the respondents to rate 46 items on how local community involvement namely, participation in decision making, knowledge sharing, empowerment, and community knowledge about tourism attempted to influence sustainable rural tourism development namely, social, cultural, economic, and environmental sustainability in these rural tourism destinations. This items were adapted from the work of Tosun (2006), Bachleitner and Zins (1999), Liao, Chang, Cheng, and Kuo (2004), Van Den Hooff, Vijvers, and De Ridder (2003), Boley and McGehee (2014), Van Niekerk and Saayman (2013), Davis, Allen, and Cosenza (1988), Delamere (2001), Tatoglu, Erdal, Ozgur, and Azakli (1998), and Dowling (1993), as shown in the Appendix.

The question items were modified to adapt the existing rural tourism in Kuching, Sarawak, Malaysia. Respondents were asked to rate their perception on participation in decision making, knowledge sharing, empowerment, and community knowledge about tourism using the 7-point Likert scale with: $7=$ strongly agree, $6=$ agree, 5 = slightly agree, $4=$ neither agree nor disagree, $3=$ slightly disagree, $2=$ disagree, and 1 = strongly disagree, for 24 items. On the other hand, respondents were asked to rate their perception on social, cultural, economic, and environmental sustainability in their community by using 5point Likert scale with: $5=$ strongly agree, $4=$ agree, $3=$ neither agree nor disagree, $2=$ disagree, and $1=$ strongly disagree, for 22 items.

\section{Findings}

This section presents the main results of the study. To assess the research model developed in Figure 1, SmartPLS 2.0 (M3) or known as partial least squares (PLS) was applied to analyse the data collected. As shown in Figure 1, local communities' involvement namely, participation in decision making, knowledge sharing, empowerment, and community knowledge about tourism are categorized as the independent variables whereas sustainable rural tourism development namely, social, cultural, economic, and environmental sustainability are grouped as the dependent variables. 200 re-samples were 
Community involvement and sustainable rural tourism development: perspectives from the local communities.

Local Communities' Involvement

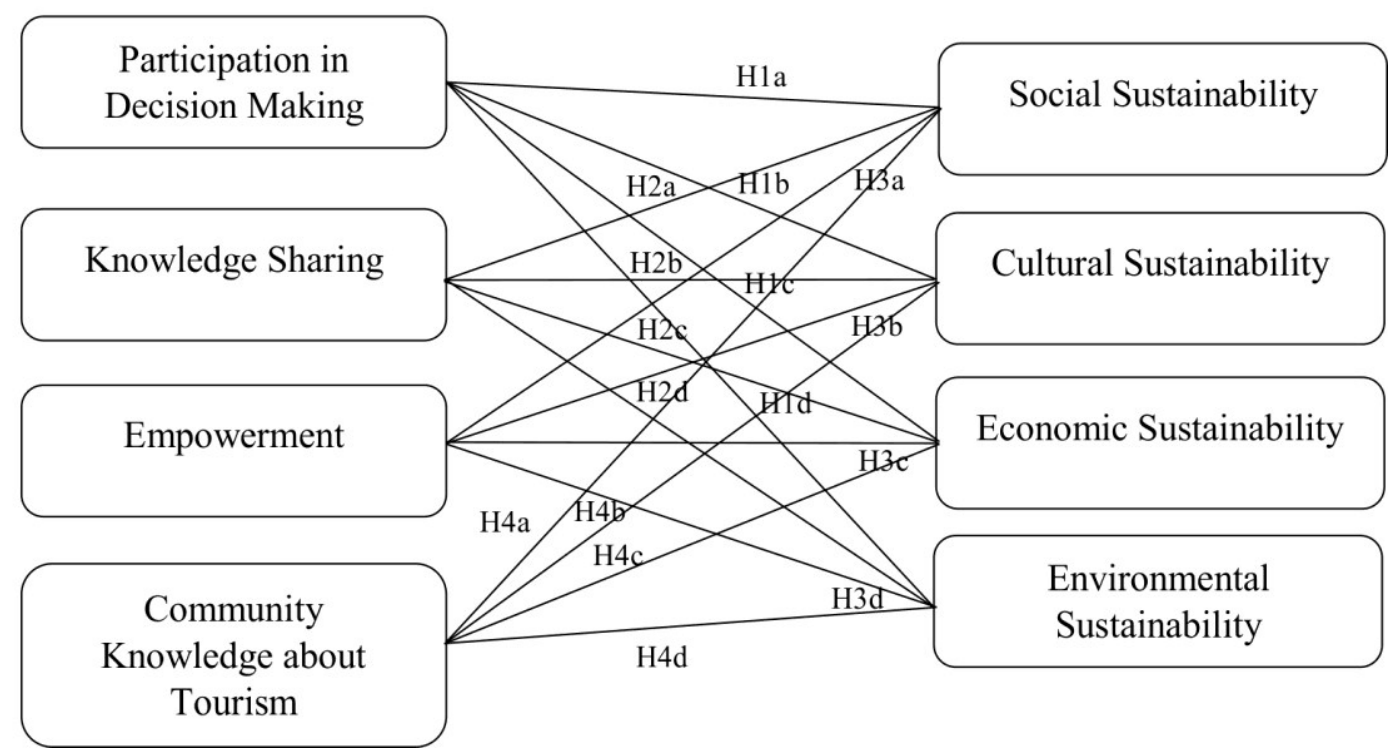

Figure 1. Research model

used to generate the standard error of the estimate and t-values.

\section{Assessment of the Measurement Model}

When the relationships among the conceptual factors of interest and the underlying construct were measured, the assessment of measurement model was conducted (Halawi \& McCarthy, 2008). Firstly, the confirmatory factor analysis (CFA) was conducted to examine the item reliability, convergent validity, and discriminant validity of the measurement scales and it was used to confirm the item's consistency to the respective construct in this study. All of the loadings were greater than the minimum cut off point of 0.5 (significant at $p<$ 0.01) (Anderson \& Gerbing, 1988; Bagozzi, Yi, \& Philipps, 1991; Gefen \& Straub, 2000), as shown in Table 1 and Table 2. Therefore, the internal consistency was achieved in this study. As shown in Table 2, out of the 46 items, 45 items were retained and 1 item namely, community knowledge about tourism 23 was discarded from the analyses due to loadings less than 0.50 as suggested by Hair, Anderson, Tatham, and Black (2006). All of the Average Variance Extracted (AVEs) are close to or exceeded 0.5 (Bagozzi \& Yi, 1988). Values of average variance extracted provided satisfactory results with the exception of cultural sustainability (0.477) and environmental sustainability (0.490), which had average variance extracted slightly below 0.5 . However, past researchers posited that it is still acceptable for construct reliability (Dumbach, 2014; Carbonell \& Rodriguez, 2006; Yli-Renko, Autio \& Sapienza, 2001). The composite reliability (CRs) exceeded 0.7 (Gefen, Straub, \& Boudreau, 2000) while the Cronbach alpha values 0.7 (Nunnally, 1978). Hence, we ensured convergent validity because all of the indicators load much higher on their hypothesized factor than on other factors, as indicated in Table 1 (Chin, 1998).

Moreover, the square root of the average variance extracted was compared in order to construct correlations and ensure discriminant validity. Most of the elements in principal diagonal are higher than the off-diagonal elements in their corresponding row and column, as indicated in Table 3 (Chin, 2010). Therefore, the measurement model was satisfactory in which there are evidences of adequate reliability, convergent validity, and discriminant validity. Next, we proceeded to test the hypotheses generated for this study. 
Table 1. Loading and cross loading

\begin{tabular}{|c|c|c|c|c|c|c|c|c|}
\hline & CK & CUL & ECO & EMP & ENV & $\mathrm{KS}$ & PDM & $\mathrm{SOC}$ \\
\hline Community Knowledge about Tourism 18 & 0.796 & 0.473 & 0.562 & 0.567 & 0.522 & 0.501 & 0.446 & 0.539 \\
\hline Community Knowledge about Tourism 19 & 0.788 & 0.451 & 0.495 & 0.581 & 0.471 & 0.614 & 0.535 & 0.515 \\
\hline Community Knowledge about Tourism 20 & 0.553 & 0.277 & 0.316 & 0.458 & 0.302 & 0.376 & 0.343 & 0.405 \\
\hline Community Knowledge about Tourism 21 & 0.778 & 0.639 & 0.495 & 0.580 & 0.552 & 0.545 & 0.432 & 0.590 \\
\hline Community Knowledge about Tourism 22 & 0.710 & 0.556 & 0.646 & 0.579 & 0.392 & 0.532 & 0.460 & 0.559 \\
\hline Community Knowledge about Tourism 24 & 0.832 & 0.576 & 0.508 & 0.609 & 0.613 & 0.578 & 0.476 & 0.578 \\
\hline Cultural Sustainability 54 & 0.401 & 0.659 & 0.514 & 0.499 & 0.450 & 0.430 & 0.413 & 0.525 \\
\hline Cultural Sustainability 55 & 0.527 & 0.689 & 0.435 & 0.377 & 0.490 & 0.375 & 0.400 & 0.647 \\
\hline Cultural Sustainability 56 & 0.574 & 0.819 & 0.607 & 0.597 & 0.564 & 0.565 & 0.501 & 0.630 \\
\hline Cultural Sustainability 57 & 0.326 & 0.564 & 0.281 & 0.385 & 0.448 & 0.408 & 0.311 & 0.365 \\
\hline Cultural Sustainability 58 & 0.548 & 0.740 & 0.553 & 0.547 & 0.621 & 0.414 & 0.403 & 0.581 \\
\hline Cultural Sustainability 59 & 0.393 & 0.645 & 0.405 & 0.377 & 0.404 & 0.387 & 0.378 & 0.575 \\
\hline Economic Sustainability 60 & 0.495 & 0.519 & 0.786 & 0.446 & 0.424 & 0.348 & 0.347 & 0.616 \\
\hline Economic Sustainability 61 & 0.434 & 0.422 & 0.747 & 0.500 & 0.327 & 0.368 & 0.372 & 0.543 \\
\hline Economic Sustainability 62 & 0.577 & 0.528 & 0.824 & 0.531 & 0.456 & 0.480 & 0.488 & 0.680 \\
\hline ic Sustainability 63 & 0.377 & 0.480 & 0.704 & 0.433 & 0.411 & 0.405 & 0.426 & 0.483 \\
\hline Economic Sustai & 0.624 & 0.609 & 0.689 & 0.569 & 0.660 & 0.490 & 0.457 & 0.676 \\
\hline Empow & 0.732 & 0.671 & 0.625 & 0.852 & 0.614 & 0.694 & 0.539 & 0.674 \\
\hline Empowerment 12 & 0.676 & 0.619 & 0.595 & 0.861 & 0.452 & 0.664 & 0.516 & 0.580 \\
\hline Empowerment 13 & 0.724 & 0.598 & 0.616 & 0.856 & 0.542 & 0.730 & 0.586 & 0.624 \\
\hline erment 14 & 0.589 & 0.483 & 0.509 & 0.839 & 0.342 & 0.643 & 0.487 & 0.494 \\
\hline Empowerment 15 & 0.456 & 0.463 & 0.469 & 0.742 & 0.269 & 0.530 & 0.603 & 0.453 \\
\hline Empowerment 16 & 0.371 & 0.330 & 0.279 & 0.601 & 0.173 & 0.480 & 0.557 & 0.340 \\
\hline Empowerment 17 & 0.490 & 0.505 & 0.497 & 0.749 & 0.280 & 0.574 & 0.588 & 0.530 \\
\hline Envir & 401 & 0.505 & 0.473 & 0.231 & 0.594 & 0.240 & 0.260 & 0.466 \\
\hline Environmental Sustainability 66 & 0.540 & 0.569 & 0.512 & 0.411 & 0.802 & 0.423 & 0.350 & 0.573 \\
\hline Environmental Sustainability 67 & 0.395 & 0.365 & 0.368 & 0.331 & 0.669 & 0.328 & 0.392 & 0.453 \\
\hline ntal Sustainability 68 & 0.417 & 0.483 & 0.292 & 0.332 & 0.764 & 0.320 & 0.251 & 0.417 \\
\hline Environmental Sustainability 69 & 0.482 & 0.591 & 0.502 & 0.463 & 0.649 & 0.434 & 0.315 & 0.463 \\
\hline Knowle & 0.602 & 0.524 & 0.484 & 0.697 & 0.524 & 0.894 & 0.641 & 0.487 \\
\hline Sharing 7 & 0.603 & 0.574 & 0.460 & 0.681 & 0.495 & 0.876 & 0.567 & 0.509 \\
\hline Knowledge Sharing 8 & 0.573 & 0.475 & 0.437 & 0.616 & 0278 & 0.811 & 0.591 & 0.417 \\
\hline Knowledge Sharing 9 & 0.660 & 0.587 & 0.585 & 0.746 & 0.477 & 0.936 & 0.664 & 0.548 \\
\hline Knowledge Sharing 10 & 0.686 & 0.601 & 0.527 & 0.746 & 0.452 & 0.910 & 0.624 & 0.573 \\
\hline Partic & 0.520 & 0.338 & 0.321 & 0.412 & 0.415 & 0.433 & 0.641 & 0.482 \\
\hline Partici & 0.341 & 0.362 & 0.403 & 0.513 & 0.212 & 0.396 & 0.691 & 0.374 \\
\hline tion in Decision Making 3 & 0.545 & 0.544 & 0.564 & 0.584 & 0.454 & 0.631 & 0.854 & 0.536 \\
\hline Participation in Decision Making 4 & 0.415 & 0.460 & 0.400 & 0.513 & 0.303 & 0.559 & 0.792 & 0.478 \\
\hline Participation in Decision Making 5 & 0.385 & 0.443 & 0.364 & 0.530 & 0.244 & 0.535 & 0.721 & 0.338 \\
\hline Social & 0.603 & 0.545 & 0.529 & 0.469 & 0.507 & 0.458 & 0.468 & 0.730 \\
\hline Social Sustai & 0.592 & 0.720 & 0.554 & 0.481 & 0.699 & 0.412 & 0.411 & 0.758 \\
\hline Social Sustainability 50 & 0.433 & 0.540 & 0.556 & 0.503 & 0.312 & 0.386 & 0.427 & 0.698 \\
\hline Social Sustainability 51 & 0.569 & 0.637 & 0.817 & 0.569 & 0.544 & 0.499 & 0.538 & 0.797 \\
\hline Social Sustainability 52 & 0.402 & 0.509 & 0.565 & 0.528 & 0.323 & 0.371 & 0.400 & 0.709 \\
\hline Social Sustainability 53 & 0.567 & 0.638 & 0.584 & 0.517 & 0.620 & 0.429 & 0.436 & 0.770 \\
\hline
\end{tabular}

Notes: $\mathrm{CK}=$ Community Knowedge about Tourism, $\mathrm{CUL}=$ Cultural Sustainability, $\mathrm{ECO}=\mathrm{E}$ conomic Sustainability, $\mathrm{EMP}=$ Empowerment, ENV=Environmental Sustainability, KS=Knowledge Sharing, PDM=Participation in Decision Making, SOC=Social Sustainability, SRTD=Sustainable Rural Tourism Development 
Community involvement and sustainable rural tourism development: perspectives from the local communities.

Table 2. Results of Measurement Model, Model Constructs, and Reliability Test

\begin{tabular}{|c|c|c|c|c|c|c|c|}
\hline Model Construct & $\begin{array}{c}\text { Measurement } \\
\text { Item }\end{array}$ & Loading & $\mathrm{t}$-value & $\begin{array}{c}\text { Cronbach's } \\
\text { Coefficient Alpha }\end{array}$ & $\begin{array}{l}\text { Number } \\
\text { of Items }\end{array}$ & $\mathrm{CR}^{\mathrm{a}}$ & $\mathrm{AVE}^{\mathrm{b}}$ \\
\hline $\begin{array}{l}\text { Community Knowledge } \\
\text { about Tourism }\end{array}$ & $\begin{array}{l}\text { CK } 18 \\
\text { CK } 19 \\
\text { CK } 20 \\
\text { CK } 21 \\
\text { CK } 22 \\
\text { CK } 24\end{array}$ & $\begin{array}{l}0.796 \\
0.788 \\
0.553 \\
0.778 \\
0.710 \\
0.832\end{array}$ & $\begin{array}{l}15.384 \\
17.492 \\
4.936 \\
20.659 \\
11.921 \\
22.248 \\
\end{array}$ & 0.840 & $7(6)$ & 0.883 & 0.560 \\
\hline Cultural Sustainability & $\begin{array}{l}\text { CUL } 54 \\
\text { CUL 55 } \\
\text { CUL 56 } \\
\text { CUL } 57 \\
\text { CUL 58 } \\
\text { CUL 59 } \\
\end{array}$ & $\begin{array}{l}0.659 \\
0.689 \\
0.819 \\
0.564 \\
0.740 \\
0.645\end{array}$ & $\begin{array}{l}7.654 \\
6.555 \\
24.255 \\
5.533 \\
11.334 \\
7.957 \\
\end{array}$ & 0.777 & $6(6)$ & 0.844 & 0.477 \\
\hline Economic Sustainability & $\begin{array}{l}\text { ECO } 60 \\
\text { ECO 61 } \\
\text { ECO 62 } \\
\text { ECO 63 } \\
\text { ECO 64 }\end{array}$ & $\begin{array}{l}0.786 \\
0.747 \\
0.824 \\
0.704 \\
0.689\end{array}$ & $\begin{array}{l}17.301 \\
12.861 \\
22.010 \\
12.242 \\
12.959 \\
\end{array}$ & 0.807 & $5(5)$ & 0.866 & 0.565 \\
\hline Empowerment & $\begin{array}{l}\text { EMP } 11 \\
\text { EMP } 12 \\
\text { EMP } 13 \\
\text { EMP } 14 \\
\text { EMP } 15 \\
\text { EMP } 16 \\
\text { EMP } 17\end{array}$ & $\begin{array}{l}0.852 \\
0.861 \\
0.856 \\
0.839 \\
0.742 \\
0.601 \\
0.749\end{array}$ & $\begin{array}{l}37.844 \\
31.024 \\
22.314 \\
24.550 \\
12.638 \\
7.223 \\
14.642 \\
\end{array}$ & 0.900 & $7(7)$ & 0.920 & 0.625 \\
\hline Environmental Sustainability & $\begin{array}{l}\text { ENV 65 } \\
\text { ENV 66 } \\
\text { ENV 67 } \\
\text { ENV 68 } \\
\text { ENV 69 }\end{array}$ & $\begin{array}{l}0.594 \\
0.802 \\
0.669 \\
0.764 \\
0.649\end{array}$ & $\begin{array}{c}6.273 \\
21.776 \\
7.692 \\
14.997 \\
9.276 \\
\end{array}$ & 0.735 & $5(5)$ & 0.826 & 0.490 \\
\hline Knowledge Sharing & $\begin{array}{l}\text { KS } 6 \\
\text { KS } 7 \\
\text { KS } 8 \\
\text { KS } 9 \\
\text { KS } 10\end{array}$ & $\begin{array}{l}0.894 \\
0.876 \\
0.811 \\
0.936 \\
0.910\end{array}$ & $\begin{array}{l}36.722 \\
34.132 \\
17.710 \\
80.113 \\
45.268 \\
\end{array}$ & 0.931 & $5(5)$ & 0.948 & 0.786 \\
\hline $\begin{array}{l}\text { Participation in } \\
\text { Decision Making }\end{array}$ & $\begin{array}{l}\text { PDM } 1 \\
\text { PDM } 2 \\
\text { PDM } 3 \\
\text { PDM } 4 \\
\text { PDM } 5\end{array}$ & $\begin{array}{l}0.641 \\
0.691 \\
0.854 \\
0.792 \\
0.721\end{array}$ & $\begin{array}{l}9.285 \\
8.720 \\
32.407 \\
17.255 \\
13.772\end{array}$ & 0.795 & $5(5)$ & 0.860 & 0.553 \\
\hline Social Sustainability & $\begin{array}{l}\text { SOC } 48 \\
\text { SOC } 49 \\
\text { SOC } 50 \\
\text { SOC } 51 \\
\text { SOC } 52 \\
\text { SOC } 53\end{array}$ & $\begin{array}{l}0.730 \\
0.758 \\
0.698 \\
0.797 \\
0.709 \\
0.770\end{array}$ & $\begin{array}{c}12.845 \\
18.520 \\
10.144 \\
18.873 \\
9.947 \\
15.568\end{array}$ & 0.839 & $6(6)$ & 0.881 & 0.554 \\
\hline \multicolumn{8}{|c|}{ Final items numbers (initial numbers) } \\
\hline $\begin{array}{l}\text { Note: }{ }^{\circ} \text { Composite Reliability } \\
\text { loadings) + (square of the sur } \\
\text { the factor loadings }) /\{(\text { summa } \\
\text { Note: CK=Community Kr } \\
\text { EMP=Empowerment, ENV= } \\
\text { SOC=Social Sustainability }\end{array}$ & $\begin{array}{l}y(C R)=(\text { squa } \\
\text { ummation of th } \\
\text { nation of the sq } \\
\text { Knowledge a } \\
=\text { Environmenta }\end{array}$ & $\begin{array}{l}\text { the su } \\
\text { ir varia } \\
\text { of the } f \\
\text { Tour } \\
\text { tainab }\end{array}$ & $\begin{array}{l}\text { on of th } \\
\text { bAvera } \\
\text { Dadings } \\
C U L=C \\
S=\text { Kno }\end{array}$ & $\begin{array}{l}\text { tor loadings)/ }\{(\mathrm{s} \\
\text { rriance Extracted } \\
\text { ummation of the } \\
\text { al Sustainabilit } \\
\text { e Sharing, PD }\end{array}$ & $\begin{array}{l}\text { of the } \\
=\text { (sum } \\
\text { ariance } \\
\mathrm{CO}=\mathrm{Ec} \\
\text { icipatio }\end{array}$ & $\begin{array}{l}\text { hic SL } \\
\text { Decisi }\end{array}$ & $\begin{array}{l}\text { he factor } \\
\text { square of } \\
\text { ainability, } \\
\text { Making, }\end{array}$ \\
\hline
\end{tabular}

Table 3. Discriminant Validity of Constructs

\begin{tabular}{|c|c|c|c|c|c|c|c|}
\hline & CK & CUL & $\mathrm{ECO}$ & EMP & ENV & KS & PDC \\
\hline Community Knowledge about Tourism & 0.748 & & & & & & \\
\hline Cultural Sustainability & 0.680 & 0.691 & & & & & \\
\hline Economic Sustainability & 0.684 & 0.690 & 0.752 & & & & \\
\hline Empowerment & 0.754 & 0.682 & 0.669 & 0.791 & & & \\
\hline Environmental Sustainability & 0.647 & 0.726 & 0.622 & 0.516 & 0.700 & & \\
\hline Knowledge Sharing & 0.706 & 0.626 & 0.565 & 0.789 & 0.509 & 0.887 & \\
\hline Participation in Decision Making & 0.601 & 0.586 & 0.563 & 0.687 & 0.451 & 0.696 & 0.744 \\
\hline Social Sustainability & 0.716 & 0.807 & 0.811 & 0.686 & 0.684 & 0.576 & 0.6020 .744 \\
\hline
\end{tabular}

Note: Diagonals represent the square root of the average variance extracted while the other entries represent the correlations.

Note: $\quad \mathrm{CK}=$ Community Knowledge about Tourism, CUL=Cultural Sustainability, ECO=Economic Sustainability,

$\mathrm{EMP}=$ Empowerment, ENV=Environmental Sustainability, KS=Knowledge Sharing, PDM=Participation in Decision Making,

$\mathrm{SOC}=$ Social Sustainability 


\section{Assessment of the Structural Model}

Secondly, Figure 2 and Table 4 demonstrate the results of hypotheses testing. The results showed that three hypotheses were found to be significantly related to sustainable rural tourism development. The results have shown that three hypotheses, namely, participation in decision making $(\mathrm{H} 1)$, empowerment $(\mathrm{H} 3)$, and community knowledge about tourism $(\mathrm{H} 4)$ were supported whereas, knowledge sharing $(\mathrm{H} 2)$ were not supported.

Next, global fit measure (GoF) assessment was conducted to test the global validation of PLS model (Chin, 1998). We estimated the GoF values (see Formula 1), which may serve as the cut-off values for global validation of PLS models. The GoF value of 0.548 (average $R^{2}$ was 0.522, average AVE was 0.576) exceeded the cut-off value of 0.36 for large effect sized of $\mathrm{R}^{2}$ and this research model had performed well in comparison with the baseline values $\left(G o F_{\text {small }}=0.1, \quad G o F_{\text {medium }}=0.25, \quad\right.$ and $\mathrm{GoF}_{\text {large }}=0.36$ for GoF) (Akter, D'Ambra, \& Ray, 2011). Therefore, this indicated that the GoF value was adequate to support the validation of PLS model globally (Wetzels, Schroder, \& Oppen, 2009).

$$
\text { GoF }=\sqrt{\overline{A V E} \times \bar{R}^{2}}
$$

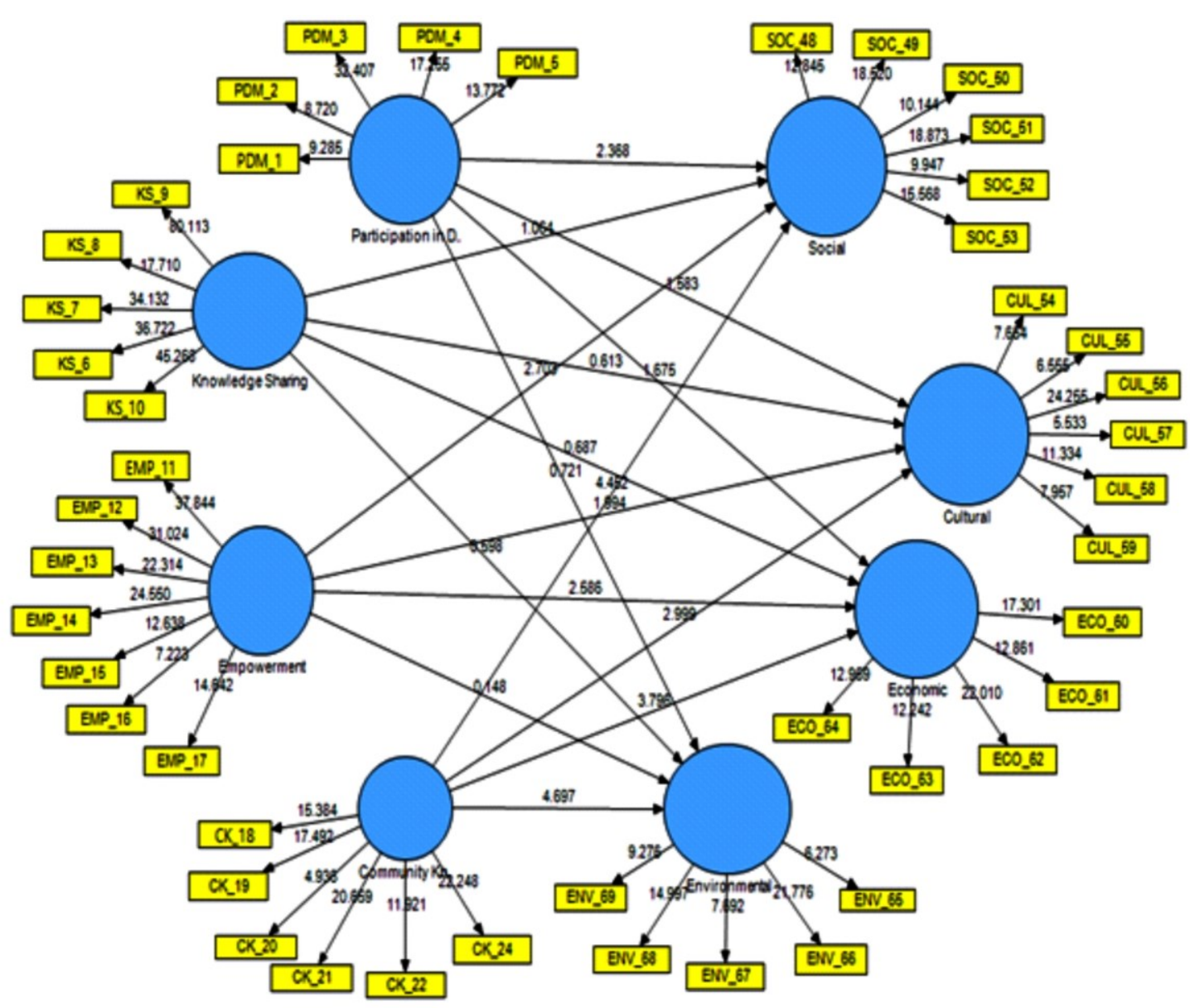

Figure 2. Research model with $t$-values

Note: $\mathrm{PDM}=$ Participation in Decision Making, $\mathrm{KS}=$ Knowledge Sharing, EMP=Empowerment, CK=Community Knowledge about Tourism, SOC=Social Sustainability, CUL=Cultural Sustainability, $\mathrm{ECO}=$ Economic Sustainability, ENV=Environmental Sustainability 
Community involvement and sustainable rural tourism development: perspectives from the local communities.

Table 4: Path Coefficients and Hypothesis Testing

\begin{tabular}{|c|c|c|c|c|}
\hline Hypothesis & Relationship & alue & t-value & Supported \\
\hline $\mathrm{H} 1$ & $\begin{array}{l}\text { Participation in decision making will have } \\
\text { positive relationship on sustainable rural } \\
\text { tourism development. }\end{array}$ & & & Partially Supported \\
\hline $\mathrm{H} 1 \mathrm{a}$ & $\begin{array}{l}\text { Participation in decision making will have } \\
\text { positive relationship on social sustainability. }\end{array}$ & 0.216 & $2.368^{\star \star}$ & Supported \\
\hline $\mathrm{H} 1 \mathrm{~b}$ & $\begin{array}{l}\text { Participation in decision making will have } \\
\text { positive relationship on cultural sustainability. }\end{array}$ & 0.148 & 1.583 & Not Supported \\
\hline $\mathrm{H} 1 \mathrm{c}$ & $\begin{array}{l}\text { Participation in decision making will have } \\
\text { positive relationship on economic sustainability. }\end{array}$ & 0.155 & $1.675^{\star}$ & Supported \\
\hline $\mathrm{H} 1 \mathrm{~d}$ & $\begin{array}{l}\text { Participation in decision making will have } \\
\text { positive relationship on environmental sustainability. }\end{array}$ & 0.073 & 0.721 & Not Supported \\
\hline $\mathrm{H} 2$ & $\begin{array}{l}\text { Knowledge sharing will have positive relationship } \\
\text { on sustainable rural tourism development. }\end{array}$ & & & Not Supported \\
\hline $\mathrm{H} 2 \mathrm{a}$ & $\begin{array}{l}\text { Knowledge sharing will have positive relationship } \\
\text { on social sustainability. }\end{array}$ & -0.131 & 1.064 & Not Supported \\
\hline $\mathrm{H} 2 \mathrm{~b}$ & $\begin{array}{l}\text { Knowledge sharing will have positive relationship } \\
\text { on cultural sustainability. }\end{array}$ & 0.072 & 0.613 & Not Supported \\
\hline $\mathrm{H} 2 \mathrm{c}$ & $\begin{array}{l}\text { Knowledge sharing will have positive relationship } \\
\text { on economic sustainability. }\end{array}$ & -0.085 & 0.687 & Not Supported \\
\hline $\mathrm{H} 2 \mathrm{~d}$ & $\begin{array}{l}\text { Knowledge sharing will have positive relationship } \\
\text { on environmental sustainability. }\end{array}$ & 0.073 & 0.598 & Not Supported \\
\hline $\mathrm{H} 3$ & $\begin{array}{l}\text { Empowerment will have positive relationship } \\
\text { on sustainable rural tourism development. }\end{array}$ & & & Partially Supported \\
\hline $\mathrm{H} 3 \mathrm{a}$ & $\begin{array}{l}\text { Empowerment will have positive relationship } \\
\text { on social sustainability. }\end{array}$ & 0.300 & $2.703^{\star \star}$ & Supported \\
\hline $\mathrm{H} 3 \mathrm{~b}$ & $\begin{array}{l}\text { Empowerment will have positive relationship } \\
\text { on cultural sustainability. }\end{array}$ & 0.269 & $1.994^{*}$ & Supported \\
\hline $\mathrm{H} 3 \mathrm{c}$ & $\begin{array}{l}\text { Empowerment will have positive relationship } \\
\text { on economic sustainability. }\end{array}$ & 0.322 & $2.586^{\star \star}$ & Supported \\
\hline $\mathrm{H} 3 \mathrm{~d}$ & $\begin{array}{l}\text { Empowerment will have positive relationship } \\
\text { on environmental sustainability. }\end{array}$ & -0.018 & 0.148 & Not Supported \\
\hline $\mathrm{H} 4$ & $\begin{array}{l}\text { Community knowledge about tourism will have } \\
\text { positive relationship on sustainable rural } \\
\text { tourism development. }\end{array}$ & & & Supported \\
\hline $\mathrm{H} 4 \mathrm{a}$ & $\begin{array}{l}\text { Community knowledge about tourism will have } \\
\text { positive relationship on social sustainability. }\end{array}$ & 0.453 & $4.452^{\star \star}$ & Supported \\
\hline $\mathrm{H} 4 \mathrm{~b}$ & $\begin{array}{l}\text { Community knowledge about tourism will have } \\
\text { positive relationship on cultural sustainability. }\end{array}$ & 0.337 & $2.999^{\star *}$ & Supported \\
\hline $\mathrm{H} 4 \mathrm{c}$ & $\begin{array}{l}\text { Community knowledge about tourism will have } \\
\text { positive relationship on economic sustainability. }\end{array}$ & 0.407 & $3.796^{\star \star}$ & Supported \\
\hline $\mathrm{H} 4 \mathrm{~d}$ & $\begin{array}{l}\text { Community knowledge about tourism will have } \\
\text { positive relationship on environmental sustainability. }\end{array}$ & 0.566 & $4.697^{\star \star}$ & Supported \\
\hline
\end{tabular}

${ }^{*} p<0.05, \mathrm{t}$-value greater than 1.645 .

${ }^{* *} \mathrm{p}<0.01$, t-value greater than 2.33 .

\section{Discussion}

Local community in tourism plays an important role in achieving long-term tourism development. Gunn and Var (2002) and Hall (2005) postulated that local community participation in tourism planning and in decision making will lead to long term social, cultural, economic, and environmental benefits to the community. Past researchers have highlighted that local community is a socio-anthropological concept who is familiar with the local culture and environment which can impress the tourists and have significant impact on sustainable rural tourism development (Rid, Ezeuduji, Probstl-Haider, 2014; Hwang, Stewart, \& Ko, 2012; Dorobantu \& Nistoreanu, 2012; Ertuna \& Kirbas, 2012; Thongma et al., 2011; Ruiz-Ballesteras, 2011; Hampton, 2005). 
Past researches on sustainable rural tourism development had mainly focused on developed countries in Europe or North America, and there are not many in the Asian continent (Chaudhry \& Tewari, 2010). Thus, this study investigates local communities' involvement on sustainable rural tourism development in Kampung Annah Rais and Kampung Darul Islam Belimbing, Kuching. The findings from this research study evidenced that local community's participation in decision making, empowerment, and community knowledge about tourism have great impact on achieving long term sustainable rural tourism development in these rural tourist destinations. However, findings indicated that knowledge sharing does not have positive relationship on sustainable rural tourism development.

Firstly, the resulting analysis for hypothesis one $(\mathrm{H} 1)$ indicated that participation in decision making has a positive relationship on sustainable rural tourism development. Findings showed that participation in decision making has a positive relationship with social sustainability $(\mathrm{H} 1 \mathrm{a})$ and economic sustainability $(\mathrm{H} 1 \mathrm{c})$ and it is consistent with the findings of Murphy (2013) and Murphy (1985) that communities who participate in decision making process will have great influence on the communities' social lifestyle and economic development in a tourist destination. On the other hand, participation in decision making was not found to have positive relationships with cultural sustainability (H1b) and environmental sustainability (H1d). These findings contrasted with the findings of Hardy, Beeton, and Pearson (2002) that local communities' involvement in decision making process is the key element in sustaining the cultural products in a tourist destination. Besides, these findings also contrasted with the findings of Roseland (2012) that a community who have authority in the decision making process will ensure that the natural environment in a tourist destination is conserved and protected. As such, it is believed that there are some restrictions that hinder the local communities to participate in the decision making process when it is related to the cultural and environmental issues in Kampung Annah Rais and Kampung Darul Islam Belimbing. As stated by Tosun (2006), there are tourism authorities who are opposed to the idea of local communities' involvement in rural tourism development. Thus, $\mathrm{H} 1$ was partially supported.

Surprisingly, hypothesis two $(\mathrm{H} 2)$ showed that knowledge sharing was not found to have a positive relationship on sustainable rural tourism development. Findings indicated that knowledge sharing does not have positive relationships with social $(\mathrm{H} 2 \mathrm{a})$, cultural $(\mathrm{H} 2 \mathrm{~b})$, economic $(\mathrm{H} 2 \mathrm{c})$, and environmental $(\mathrm{H} 2 \mathrm{~d})$ sustainability. The findings contrasted with the findings by Nadkarni (2008) that community who share their knowledge with tourism stakeholders will increase the stakeholder's awareness towards the social lifestyle and traditional way of life of the local communities. Besides, the results contrasted with the findings by Di Castri and Balaji (2002) that effective knowledge sharing will bring economic benefits to the tourist destination. Moreover, the findings also contrasted with the findings by Camarinha-Matos and Afsarmanesh (2006) that knowledge sharing will ensure that the stakeholders will cooperate to achieve tourism development and environmental protection goals. It is believed that these contrasted results might be due to weak or poor relationship among the tourism stakeholders which reduces the level of cooperation to achieve social, cultural, economic, and environmental sustainability in both Kampung Annah Rais and Kampung Darul Islam Belimbing. This is supported by Hansen (1999) that the existence of a strong or weak relationship among the members will determine the effectiveness of knowledge sharing. Therefore, $\mathrm{H} 2$ was not supported.

Next, the resulting analysis for hypothesis three (H3) indicated that empowerment has a positive relationship on sustainable rural tourism development. Findings indicated that empowerment has positive relationships with social (H3a), cultural (H3b), and economic $(\mathrm{H} 3 \mathrm{c})$ sustainability. These findings were in line with the findings of Cole (2006) that empowerment is positively associated with social sustainability. Local communities could improve their quality of life when they are empowered in tourism development. Besides, the findings were congruent with the findings of 
Goodwin and Santilli (2009) that community empowerment is positively related to cultural sustainability in a tourist destination. Local communities who are in control of tourism development will ensure that the cultural integrity in the community are maintained and preserved. Furthermore, the findings were also congruent with the findings of Sebele (2010) that empowerment is positively related to livelihoods and economic development in a community. Locals who take control over tourism development will have a better standard of living in the community. Interestingly, findings showed that empowerment do not have a positive relationship with environmental sustainability $(\mathrm{H} 3 \mathrm{~d})$. These findings contrasted with the findings of Dwyer (2005) that community empowerment will lead to environmental sustainability. It is believed that this contrasted result was due to the lack of trust between the local communities and tourism authorities in Kampung Annah Rais and Kampung Darul Islam Belimbing. Tourism authorities might not give full authority to the local communities to deal with the environmental issues in these tourist destinations. Therefore, H3 was partially supported.

Lastly, hypothesis four $(\mathrm{H} 4)$ showed that there is a positive relationship between community knowledge about tourism and sustainable rural tourism development. As shown in Table 4, community knowledge about tourism has a positive relationship with social $(\mathrm{H} 4 \mathrm{a})$, cultural $(\mathrm{H} 4 \mathrm{~b})$, economic $(\mathrm{H} 4 \mathrm{c})$, and environmental $(\mathrm{H} 4 \mathrm{~d})$ sustainability. These findings were in line with the findings by Nadkarni (2008) that community knowledge about tourism is the capability that can be used to protect the social fabric of a tourist destination and it is important to protect the tradition, beliefs, and norms in a community. Moreover, this finding were congruent with the findings of Sebele (2010) that local communities who are aware of the cost and benefits of tourism will utilise the resources wisely and in turn sustain the local economy. Besides, the findings were in line with the findings of Jamal and Stronza (2009) that environmental protection, conservation, and sustainable practices depend on the local knowledge about tourism. Community who have the knowledge about tourism will not be taken advantage by the tourism authorities who want to exploit the land and resources of the community. Thus, H4 was supported.

\section{Implications}

This research has a number of theoretical and practical implications for both scholars and practitioners, particularly in the domain of sustainable rural tourism development. Firstly, this study represents the theoretical or empirical research about the involvement of the local communities in sustainable rural tourism development. In the past, there have been limited empirical researches on local communities' involvement on achieving social, cultural, economic, and environmental sustainability, more so from the communities' perspective. Hence, the framework of this research provides a better understanding of how local communities' involvement namely, participation in decision making, knowledge sharing, empowerment, and community knowledge about tourism will have a tremendous impact on sustainable rural tourism development. Secondly, this study provide useful guidelines for the scholars who are interested on the study of sustainable rural tourism development. Without any doubt, the research on sustainable rural tourism development from the communities' perspectives is still limited in its ability to provide an unequivocal guideline.

It is believed that local communities' involvement in rural tourism development is needed because it is the key to achieve sustainable rural tourism development. This research would have added value to the literature on sustainable rural tourism development, especially in Sarawak settings since there are limited literatures on similar setting. Moreover, this study enables tourism stakeholders to recognize the importance of involving local communities in rural tourism development. As such, this would have a significant contribution to sustainable rural tourism development given the fact that if tourism stakeholders realise the importance of local communities' involvement, they would achieve better performance and in turn achieve sustainable rural tourism development. 


\section{Limitation and Direction for Future Research}

There are restrictions and limitations during the development and implementation of this research. Firstly, the sample size is small to generalize the results to other rural tourist destinations. However, the results have served as a basic research for future discussion on local communities' involvement and sustainable rural tourism development. Secondly, this study was cross-sectional in which the data were obtained in a single period of time and can only provide a static perspective on fit. Next, the setting of this study was conducted in the rural tourism of Kuching, Sarawak, Malaysia. For further studies, it would be interesting to test the variables in other rural regions to see if the reliability and validity persist.

\section{Conclusion}

It is believed that the findings have provided a compelling evidence for the importance of local communities' involvement on sustainable rural tourism development. Although local communities' involvement have been studied in previous researches, no known researches have been found to empirically study specifically on each of the dimensions of sustainable rural tourism development namely, social, cultural, economic, and environmental sustainability in rural tourism destinations in Kuching, Sarawak context. As such, it is worth to investigate the impact of local communities' involvement on sustainable rural tourism development in Kuching, Sarawak. This study would evoke tourism stakeholders about the importance of local communities' involvement in achieving sustainable rural tourism development. Besides, this research claims to identify the existence of local communities' involvement on sustainable rural tourism development from the communities' point of view. Results have shown that local communities' participation in decision making, empowerment, and community knowledge about tourism are the important elements in achieving sustainability in rural tourism development. This is so because local communities are the residents in these rural tourism destinations and they have the knowledge about their own community to make decisions which will benefit the destinations. Besides, they are familiar with their own social, culture, and environment and this knowledge can be used to attract the tourists and in turn sustain the social, cultural, economic, and environmental development in these tourist destinations. Further, results also indicated that knowledge sharing do not have a positive relationship on sustainable rural tourism development. As such, knowledge sharing should be encouraged to improve the information flow among the tourism stakeholders and a good relationship between the local communities and tourism stakeholder is important to achieve effective knowledge sharing in both Kampung Annah Rais and Kampung Darul Islam Belimbing. Therefore, since rural tourism is favourable and highly demanded among tourists, it is crucial to understand the importance of local communities' involvement in achieving sustainable rural tourism development.

\section{Acknowledgement:}

This paper was supported by Universiti Malaysia Sarawak and Ministry of Higher Education, Malaysia under the Long Term Research Grant Scheme 2011 [LRGS grant no: JPT.S (BPKI) 2000/09/01/015Jld.4(67)]

\section{References}

Aas, C., A. Ladkin, J. Fletcher (2005) Stakeholder collaboration and heritage management. Annals of Tourism Research 32 (1), 28-48

Akter, S., J. D'Ambra, P. Rray, P (2011) Trustworthiness in health information services: An assessment of a hierarchical model with mediating and moderating effects using partial least squares (PLS). Journal of the American Society for Information Science and Technology 62 (1), 100-116

Alavi, M., D. E. Leidner (2001) Review: Knowledge management and knowledge management systems: Conceptual foundations and research issues. MIS Quarterly 25 (1), 107-136

Andereck, K. L., K. M. Valentine, R. C. Knopf, C. A. Vogt (2005) Residents perceptions of community tourism impacts. Annals of Tourism Research, 32 (4), 1056-1076

Anderson, J. C., D. W. Gerbing (1988) Structural equation modelling in 
practice: A review and recommended two-step approach. Psychological Bulletin 103 (3), 411-423

Archer, B., C. Cooper, L. Ruhanen (2005) The positive and negative impacts of tourism. In Theobald, W. F. (ed.) (2005) Global Tourism. Routledge, 79102

Arnstein, R. S. (1969) A ladder of citizen participation. Journal of American Institute of Planners 35 (4), 216-224

Bachleitner, R., A. H. Zins (1999) Cultural tourism in rural communities: The residents' perspective. Journal of Business Research 44 (3), 199-209

Bhuiyan, M. A. H. (2010) Employee participation in decision making in RMG sector of Bangladesh: Correlation with motivation and performance. Journal of Business and Technology (Dhaka) 5 (2), 122-132

Bogozzi, R. P., Y. Yi (1988) On the evaluation of structural equation models. Journal of the Academy of Marketing Science 16 (1), 74-94

Bogozzi, R. R., Y. Yi, L. W. Philipps (1991) Assesing construct validity in organizational research. Administrative Science Quarterly 36 (3), 421-458

Boley, B., N. McGehee (2014) Measuring empowerment: developing and validating the resident empowerment through tourism scale (RETS). Tourism Management 45, 85-94

Briedenhann, J., E. Wickens (2004) Tourism routes as a tool for the economic development of rural areas-vibrant hope or impossible dream? Tourism Management 25 (1), 71-79

Brunt, P., P. Courtney (1999) Host perceptions of socio-cultural impacts. Annals of Tourism Research 26 (3), 493-515

Camarinha-Matos, L. M., H. Afsarmanesh (2006) Collaborative Networks: Value Creation in a Knowledge Society. In Wang, K., G. Kovacs, M. Wozny, M. Fang (ed.) (2006) Knowledge Enterprise: Intelligent Strategies in Product Design, Manufacturing, and Management. Boston: Springer, 26-40

Carbonell, P., A. I. Rodriguez (2006) Designing teams for speedy product development: The moderating effect of technological complexity. Journal of Business Research 59 (2), 225-232

Cohen, S. G., D. E. Bailey (1997) What makes team work: group effectiveness research from the shop floor to the executive suite. Journal of Management 23 (3), 239-290

Caneday, L., J. Zieger (1991) The social, economic, and environmental costs of tourism to a gaming community as perceived its residents. Journal of Travel Research 30 (2), 45-49

Chaudhry, P., V. P. Tewari (2010) Managing urban parks and gardens in developing countries: A case from an Indian city. International Journal of Leisure and Tourism Marketing 1 (3), 248-256

Choi, H. C., I. Murray (2010) Resident attitudes toward sustainable community tourism. Journal of Sustainable Tourism 18 (4), 575-594

Choibamroong, T. T. (2011) A stakeholder approach for sustainable communitybased rural tourism development in Thailand. In Laws, E., H. Richins, J. Agrusa, N. Scott (ed.) (2011) Tourist destination governance: Practice, theory and issues. Cabi, 173-186

Chin, W. W. (1988) The partial least squares approach to structural equation modeling. Modern Methods for Business Research 295 (2), 295-336

Chin, W.W. (2010) How to write up and report PLS analyses. In Vinzi, V. E., W. W. Chin, J. Henseler, H. Wang (ed.) (2010) Handbook of partial least squares: Concept, methods and applications. Berlin Heidelberg: Springer-Verlag, 655-690

Cole, S. (2006) Information and empowerment: The keys to achieving sustainable tourism. Journal of Sustainable Tourism 14 (6), 629-644

Cooper, C. (2006) Knowledge management and tourism. Annals of Tourism Research 35 (1), 47-64

Coria, J., E. Calfucura (2012) Ecotourism and the development of indigenous communities: The good, the bad, and the ugly. Ecological Economics 73, 4755

Costa, C. (2001) An emerging tourism planning paradigm? A comparative analysis 
between town and tourism planning. International Journal of Tourism Research 3 (6), 425-441

Cowley, M., D. A. Gillmor (2008) Integrated rural tourism: Concepts and practice. Annals of Tourism Research 35 (2), 316-337

Davis, D., J. Allen, R. M. Cosenza (1988) Segmenting local residents by their attitudes, interests, and opinions toward tourism. Journal of Travel Research 27 (2), 2-8

Deery, M., L. Jago, L. Fredline (2012) Rethinking social impacts of tourism research: a new research agenda. Tourism Management 33 (1), 64-73

Delamere, T. A. (2001) Development of a scale to measure resident attitudes toward the social impacts of community festivals, part II: Verification of the scale. Event Management 7, 25-38

Di Castri, F., V. Balaji (2002) Tourism, biodiversity and information. Leiden: Backhuys.

Dogra, R., A. Gupta (2012) Barriers to community participation in tourism development: Empirical evidence from a rural destination. South Asian Journal of Tourism and Heritage 5 (1), 219-142

Dolnicar, S. (2006) Nature-conserving tourists: The need for a broader perspective. Anatolia: An International Journal of Tourism and Hospitality Research 17 (2), 235-255

Dorobantu, M. R., P. Nistoreanu (2012) Rural tourism and ecotourism-the main priorities in sustainable development orientations of rural local communities in Romania. Economy Transdisciplinarity Cognition 15 (1) 259-266

Dowling, R. K. (1993) Tourist and resident perceptions of the environment-tourism relationship in the Gascoyne Region, Western Australia. GeoJournal 29 (3), 243-251

Dumbach, M. (2014) Establishing corporate innovation communities: $A$ social capital perspective. Imprint: Springer Gabler.

Dwyer, L. (2005) Relevance of triple bottom line reporting to achievement of sustainable tourism: A scoping study.
Tourism Review International 9 (1), 79938

Ertuna, B., G. Kirbas (2012) Local community involvement in rural tourism development: The case of Kastamonu, Turkey. Revistade Turismoy Patrimonio Culture, 10 (2), 17-24

Eshliki, S. A., M. Kaboudi (2012) Community perception of tourism impacts and their perception in tourism planning: A case study of Ramsar, Iran. Procedia-Social and Behavioral Science 36, 333-341

Fahy, J. (2000) The resource-based view of the firm: Some stumbling-blocks on the road to understand sustainable competitive advantage. Journal of European Industrial Training 24 (2/3/4), 94-104

Fahy, J., A. Smithee (1999) Strategic marketing and the resource based view of the firm. Academy of Marketing Science Review 10 (1), 1-21

Fiorello, A., D. Bo, D. (2012) Community-based ecotourism to meet the new tourist's expectations: An exploratory study. Journal of Hospitality Marketing \& Management 21 (7), 758-778

Gefen, D., D. Straub (2000) The relative importance of perceived ease-of-use in IS adoption: A Study of e-Commerce Adoption. Journal of the Association for Information Systems 1 (1), 1-28

Gefen, D., D. W. Straub, M. C. Boudreau (2000) Structural equation modeling and regression: Guidelines for research practice. Communications of the Association for Information Systems 4 (7), 1-70

Goodwin, H., R. Santilli (2009) Communitybased tourism: A success? ICRT Occasional Paper, 11 (1), 1-37

Gunn, C., T. Var (2002) Tourism planning: basics, concepts, cases. Psychology Press.

Gursoy, D., D. G. Rutherford (2004) Host attitudes towards tourism-an improved structural model. Annals of Tourism Research 31 (3), 495-516

Hair, J. F., R. E. Anderson, R. L. Tatham, W. C. Black (2006). Multivariate Data Analysis with Readings ( $4^{\text {th }}$ ed.). Englewood Cliff, NJ: Prentice Hall. 
Halawi, L., R. McCarthy (2008) Measuring students perceptions of blackboard using the technology acceptance model: A PLS approach. Issues in Information Systems, 9 (2), 95-102

Hall, C. M. (2005) Tourism: Rethinking the social science of mobility. Harlow: Prentice-Hall.

Hall, D. R. (2011) Tourism development in contemporary central and Eastern Europe: challenges for the industry and key issues for researchers. Human Geographies-Journal of Studies and Research in human Geography 5 (2), 5-12

Hampton, M. P. (2005) Heritage, local communities and economic development. Annals of Tourism Research 32 (3), 735-759

Hansen, M. (1999) The search-transfer problem: The role of weak ties in sharing knowledge across organization subunits. Administrative Science Quarterly 44 (1), 82-111

Hardy, A., R. J. S. Beeton, L. Pearson (2002) Sustainable Tourism: An Overview of the Concept and its Position in Relation to Conceptualisation of Tourism. Journal of Sustainable Tourism, 10 (6), 475-496

Heller, F. A., E. Pusic, G. Strauss, B. Wilpert (1998) Organizational participation: myth and reality. New York, NY: Oxford University Press.

Henry, A. (2008) Understanding strategic management. Oxford University Press, New York.

Hjalager, A. M. (2010) A review of innovation research in tourism. Tourism Management 31, 1-12

Hunt, S. D., R. M. Morgan (1995) The comparative advantage theory of competition. Journal of Marketing, 59 (2), 1-15

Hwang, D., W. P. Stewart, D. W. Ko (2012) Community behavior and sustainable rural tourism development. Journal of Travel Research 51 (3), 328-341

Ipe, M. (2003) Knowledge sharing in organizations: A conceptual framework. Human Resource Development Review 2 (4), 337-359
Itami, H. (1987) Mobilising invisible assets. MA: Harvard University Press, Cambridge.

Jackson, J. (2006) Developing regional tourism in China: The potential for activating business clusters in a socialist market economy. Tourism Management 27 (4), 695-706

Jackson, J., P. Murphy (2006) Clusters in regional tourism: An Australian case. Annals of Tourism Research 33 (4), 1018-1035

Jamal, T., A. Stronza (2009) Collaboration theory and tourism practice in protected areas: Stakeholders, structuring and sustainability. Journal of Sustainable Tourism, 17 (2), 169189

Lee, T. H. (2013) Influence analysis of community resident support for sustainable tourism development. Tourism Management 34, 37-46

$\mathrm{Li}$, W. (2006) Community decision making participation in development. Annals of Tourism Research 33 (1), 132-143

Liao, S. H., J. C. Chang, S. C. Cheng, C. M. Kuo (2004) Employee relationship and knowledge sharing: A case study of a Taiwanese finance and securities firm. Knowledge Management Research \& Practice 2 (1), 24-34

Liu, A. (2006) Tourism in rural areas: Kedah, Malaysia. Tourism Management 27 (5), 878-889

McAreavey, R., J. McDonagh (2011) Sustainable rural tourism: Lessons for rural development. Sociologia Ruralis 51 (2), 175-194

MacDonald, R., L. Jolliffe (2003) Cultural rural tourism: Evidence from Canada. Annals of Tourism Research 30 (2), 307-322

Matzler, K., J. Mueller (2011) Antecedents of knowledge sharing-examining the influence of learning and performance orientation. Journal of Economic Psychology 32 (3), 317-329

Moscardo, G. (2011) The role of knowledge in good governance for tourism. In Laws, R., H. Richins, J. Agrusa, N. Scott (ed.) (2011) Tourist Destination Governance: Practice, Theory and Issues. Cabi, 6780 
Mulder, M. B., C. L. Nunn, M. C. Towner (2006) Cultural macroevolution and the transmission of traits. Evolutionary Anthropology 15 (2), 52-64

Murphy, P. E. (1985) Tourism: A community approach. New York: Methuen

Murphy, P. E. (2013) Tourism: A community approach (Volume 4). London and New York: Routhledge.

Nadkarni, S. (2008) Knowledge creation, retention, exchange, devolution, interpretation and treatment (k-credit) as an economic growth driver in propoor tourism. Current Issues in Tourism, 11 (5), 456-472

Nair, V., U. T. Munikrishnan, S. D. Rajaratnam, N. King (2014) Redefining rural tourism in Malaysia: A conceptual perspective. Asia Pacific Journal of Tourism Research, 1-24

Nicholas, L., B. Thapa, Y. Ko (2009) Residents' perspectives of a world heritage sitethe pitons management area, St. Lucia. Annals of Tourism Research 36 (3), 390-412

Novelli, M., K. Gebhardt (2007) Community based tourism in Namibia: "reality show" or "window dressing"? Current Issues in Tourism 10 (5), 443-479

Nunally, J. C. (1978) Psychometric Theory. New York: NY: McGraw-Hill.

Oppermann, M. (1996) Rural tourism in Southern Germany. Annals of Tourism Research 23 (1), 86-102

Pesonen, J., R. Komppula, C. Kronenberg, M. Peters (2011). Understanding the relationship between push and pull motivations in rural tourism. Tourism Review 66 (3), 32-49

Poostchi, I. (1986) Rural development and the developing countries: An interdisciplinary countries: An interdisciplinary introductory approach. The Alger Press Ltd., Ottawa, Canada.

Rattanasuwongchai, N. (1998) Rural tourism The impact on rural communities II. Thailand. Extension Bulletin, Tai-pei, Taiwan: Food \& Fertilizer Technology Center (FFTC) 458, 4-16

Reid, D. G., H, Mair, W. George (2004) Community Tourism Planning: A SelfAssessment Instrument. Annals of Tourism Research, 31 (3), 623-639
Roseland, M. (2012) Toward sustainable communities: Solutions for citizens and their governments ( $4^{\text {th }}$ ed.). Gabriola Island: New Society Publishers.

Ruiz-Ballesteros, E. (2011) Social-ecological resilience and community-based tourism an approach from Agua Blanca, Ecuador. Tourism Management 32 (3), 655-666

Ryu, S., S. H. Ho, I. Han (2003) Knowledge sharing behavior of physicians in hospitals. Expert Systems with Applications 25 (1), 113-122

Saarinen, J. (2010) Local tourism awareness: Community views in Katutura and King Nehale Conservancy, Namibia. Development Southern Africa 27 (5), 713-724

Sanagustin Fons, M. V., J. A. M. Fierro, M. G. y Patino (2011) Rural tourism: A sustainable alternative. Applied Energy 88 (2), 551-557

Santana-Medina, N., S. Franco-Maass, E. Sanchez-Vera, J. Imbernon, G. NavaBernal (2013) Participatory Generation of Sustainability Indicators in a Natural Protected Area of Mexico. Ecological Indicators 25, 1-9

Sebele, L. S. (2010) Community-based tourism ventures, benefits and challenges: Khama Rhino sanctuary trust, central district, Botswana. Tourism Management 31 (1), 136-146

Scheyvens, R. (1999) Ecotourism and the empowerment of local communities. Tourism Management 20 (2), 245-249

Sharpley, R., J. Sharpley (1997) Rural tourism an introduction. International Thomson Business Press, London.

Shaw, G., A. Williams (2009) Knowledge transfer and management in tourism organisations: An emerging research agenda. Tourism Management 30 (3), 325-335

Simmons, D. G. (1994) Community participation in tourism planning. Tourism Management 15 (2), 98-105

Snapenger, D., R. O'Connell, M. Snepenger (2001) The embrace-withdraw continuum scale: Operationalizing residents' responses toward tourism 
Community involvement and sustainable rural tourism development: perspectives from the local communities.

development. Journal of Travel Research 40 (2), 155-161

Sofield, T. (2003) Empowerment for sustainable tourism development. Emerald Group Publishing.

Sofield, T., F. M. S. Li (2007) China: Ecotourism and cultural tourism, harmony or dissonance. In J. Higham (ed.) (2007) Critical Issues in Ecotourism: Understanding a Complex Tourism Phenomenon. Elsevier, Butterworth-Heinemann, 368-385

Sorensen, F. (2007) The geographies of social networks and innovation in tourism. Tourism Geographies 9 (1), 22-48

Spender, J. C. (1996) Making knowledge the basis of a dynamic theory of the firm. Strategic Management Journal 17 (S2), 45-62

Tatoglu, E., F. Erdal, H. Ozgur, S. Azakli (1998) Resident perceptions of the impact of tourism in a Turkish Resort Town. Leisure Sciences, 745-755

Thongma, W., W. Leelapattana, J. T. Hung (2011) Tourists' satisfaction towards tourism activities management of Maesa Community, Pongyang SubDistrict, Maerim District, Chiang Mai Province, Thailand. International Journal of Asian Tourism Management 2 (1), 86-94.

Timur, S., D. Getz (2009) Sustainable tourism development: How do destination stakeholders perceive sustainable urban tourism?. Sustainable Development 17 (4), 220-232

Tosun, C. (2000) Limits to community participation in the tourism development process in developing countries. Tourism Management 21 (6), 613-633

Tosun, C. (2006) Expected nature of community participation in tourism development. Tourism Management 27 (3), 493-504

Tosun, C., D. Timonthy (2003) Arguments for community participation in tourism development. Journal of Tourism Studies 14 (2), 2-11
Van Den Hoff, B., J. A. Ridder (2004) Knowledge sharing in context: The influence of organizational commitment, communication climate and $\mathrm{CMC}$ use on knowledge sharing. Journal of Knowledge Management 8 (6), 117-130

Van Den Hooff, B., J. Vijvers, J. De Ridder (2003) Foundations and applications of a knowledge management scan. European Management Journal 21 (2), 237-246

Van Niekerk, M., M. Saayman (2013) The influences of tourism awareness on the travel patterns and career choices of high school students in South Africa. Tourism Review 68 (4), 19-33

Warren, J., N. Taylor (1999) Developing rural tourism in New Zealand. CommArts, Wellington.

Wetzel, M., G. Odekerken-Schroder, C. Van Oppen (2009) Using PLS path modeling for assessing hierarchical construct models: Guidelines and empirical illustration. Management Information Systems Quarterly 33 (1), 177-195

World Travel and Tourism Council (WTTC), World Tourism Organization (WTO), Earth Council (1995) Agenda 21 for the travel and tourism Industry: Towards environmentally development. sustainable Council: London.

Yang, Y. (2012) Agglomeration Density and Tourism Development in China: An Empirical Research Based on Dynamic Panel Data Model. Tourism Management, 33 (6), 1347-1359

Yli-Renko, H., E. Autio, H. J. Sapienza (2001) Social capital, knowledge acquisition, and knowledge exploitation in young technology-based firms. Strategic Management Journal 22 (6-7), 857-613

Zapata, M. J., C. M. Hall, P. Lindo, M. Vanderschaeghe (2011) Can community-based tourism contribute to development and poverty alleviation? lessons from Nicaragua. Current Issues in Tourism 14 (8), 725-749 


\section{Appendix}

Items of the Questionnaire

Items of Participation in Decision Making (PDM)

PDM 1 I am informed about the tourism policies in my community.

PDM 2 I have a voice in decision making process of tourism development in my community.

PDM 3 My opinion are sought when it is about tourism development project in my community.

PDM $4 \quad$ I am consulted when it is about tourism development issues such as the selection of a local government agencies who will decide on tourism development issues in my community.

PDM $5 \quad$ I am actively involved in decision making process about tourism affairs in my community.

Source: Tosun (2006), Bachleitner \& Zins (1999)

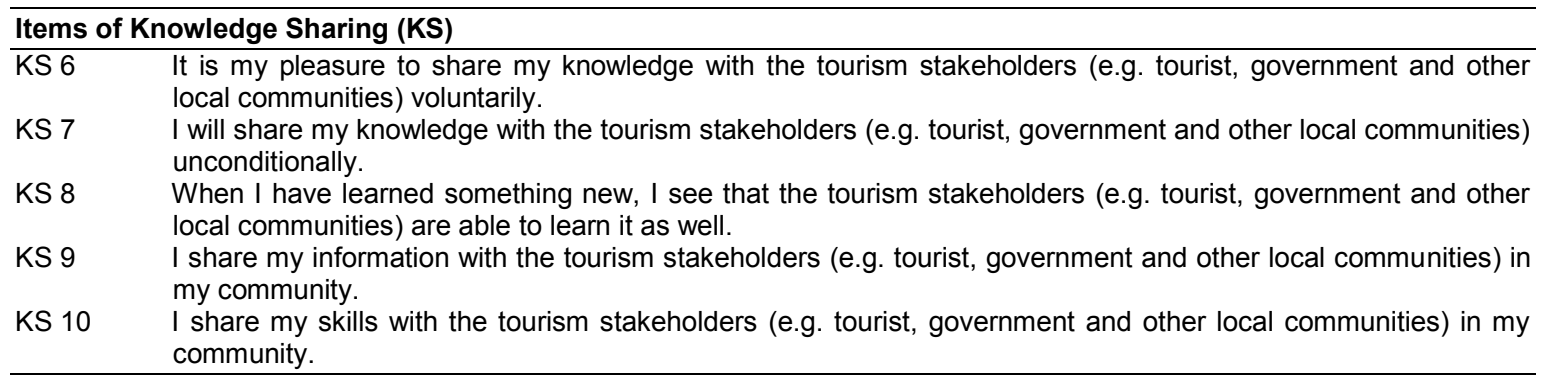

Source: Liao, Chang, Cheng, Kuo (2004); Van Den Hooff, Vijvers, De Ridder (2003)

\section{Items of Empowerment (EMP)}

EMP $11 \quad$ Tourism makes me proud to be the resident in my community.

EMP 12 Tourism makes me want to work to keep my community special.

EMP 13 Tourism in my community makes me feel more connected to my community.

EMP 14 Tourism in my community provide ways for me to get involved in my community.

EMP 15 I feel like I have a voice in my community's tourism development decisions.

EMP 16 I feel like I have access to the decision making process when it comes to tourism in my community.

EMP 17 I feel that my vote makes a difference in how tourism is developed in my community.

Source: Boley \& McGehee (2014)

\section{Items of Community Knowledge about Tourism (CK)}

CK $18 \quad$ Tourism industry in my area is an economic booster for my country.

CK 19 Tourism is visiting friends and relatives in another town.

CK 20 Eco tourism is tourism in harmony with the environment.

CK $21 \quad$ I know a lot of tourist attractions in my area.

CK 22 Tourism industry provides many worthwhile employment opportunities.

CK 23 Tourism has caused taxes to increase for Sarawak residents because of the extra police needs, roads, and so on.

CK 24 The advertising spent by the area to attract tourists to my community is a good investment.

Source: Van Niekerk \& Saayman (2013); Davis, Allen, \& Cosenza (1988)

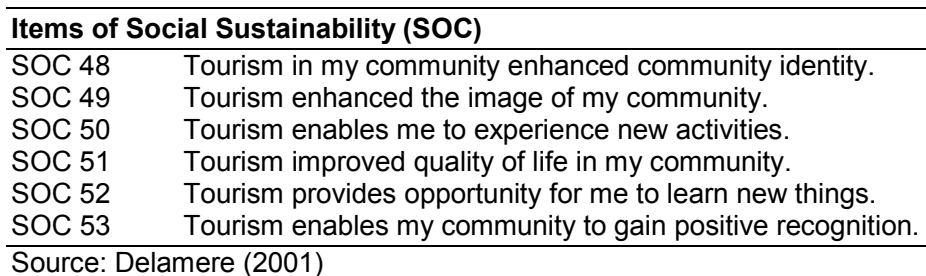

\section{Items of Cultural Sustainability (CUL)}

CUL $54 \quad$ Tourism provides opportunity for me to learn other people's cultures.

CUL $55 \quad$ Tourism provides opportunity to restore and protect historical structures in my community.

CUL 56 Tourism increase people's awareness and recognition about the local culture and heritage in my community.

CUL 57 The variety of cultural activities in my community is unique and special.

CUL 58 Tourism provides many varieties of cultural facilities and activities in my community.

CUL 59 Tourism provides many variety of entertainment in my community.

Source: Tatoglu, Erdal, Ozgur, Azakli (1998) 
Items of Economic Sustainability (ECO)

ECO $60 \quad$ Tourism increases the number of jobs in my community.

ECO 61 Tourism increases my personal income.

ECO 62 Tourism increases my standard of living.

ECO 63 Tourism provides variety of shopping facilities in my community.

ECO 64 Tourism generate revenue for the local economy.

Source: Tatoglu, Erdal, Ozgur, Azakli (1998)

\section{Items of Environmental Sustainability (ENV)}

ENV $65 \quad$ Tourism should be integrated with conservation and land management in my community.

ENV 66 Tourism development should be encouraged not to have conflict with the environment.

ENV 67 Tourism does not harm the environment.

ENV 68 The environment needs greater protection.

ENV 69 The economic gains of tourism are just as important as the protection of the environment.

Source: Dowling (1993) 